\title{
Metastatic Tumours to the Oral Cavity: Report of Three Cases
}

\author{
Ioanna G. Kalaitsidou ${ }^{1}$, Ioannis T. Astreidis ${ }^{1}$, Konstantinos I. Kontos ${ }^{1}$, Maria N. Lazaridou ${ }^{1}$, \\ Eleni T. Bourlidou ${ }^{1}$, Domniki K. Gerasimidou ${ }^{2}$, Natalia P. Vladika², Doxa L. Mangoudi ${ }^{1}$ \\ 'Department of Oral and Maxillofacial Surgery, "Theagenio" Cancer Hospital, Thessaloniki, Greece. \\ 2Department of Pathology, "Theagenio" Cancer Hospital, Thessaloniki, Greece.
}

\author{
Corresponding Author: \\ Ioanna G. Kalaitsidou \\ 53 Derkon Street, 54454, Thessaloniki \\ Greece \\ Phone: (+30) 2311-202650 / (+30)6944-351787 \\ Fax: (+30) 2310-233964 \\ E-mail: ikalalaitsidou@yahoo.gr/ikalaitsidou@gmail.com
}

\begin{abstract}
Background: Metastatic tumours to the oral cavity from distant organs are uncommon and represent approximately $1-3 \%$ of all oral malignancies. Such metastases can occur to the bone or to the oral soft tissues. Almost any malignancy from any site is capable of metastasis to the oral cavity and a wide variety of tumours have been reported to spread to the mouth.

Methods: Careful examination of the oral cavity and a high degree of clinical suspicion as well as a multidisciplinary approach are suggested.

Results: In this article we present three patients, a female and two males with metastatic tumours to the oral cavity, who were referred to our Department. The primary tumours were invasive lobular breast carcinoma, gastric adenocarcinoma and small cell lung carcinoma respectively.

Conclusions: Metastases to the oral cavity are quite uncommon among population. They usually present with symptoms similar to odontogenic infections and benign tumours, causing a delayed diagnosis and treatment.
\end{abstract}

Keywords: adenocarcinoma, breast carcinoma, oral cancer, small cell lung carcinoma.

Accepted for publication: 21 December 2015

To cite this article:

Kalaitsidou IG, Astreidis IT, Kontos KI, Lazaridou MN, Bourlidou ET, Gerasimidou DK, Vladika NP, Mangoudi DL.

Metastatic Tumours to the Oral Cavity: Report of Three Cases

J Oral Maxillofac Res 2015;6(4):e5

URL: http://www.ejomr.org/JOMR/archives/2015/4/e5/v6n4e5.pdf

doi: $\underline{10.5037 / \text { jomr.2015.6405 }}$ 


\section{INTRODUCTION}

Metastatic tumours to the oral cavity from distant organs are uncommon and represent approximately $1-3 \%$ of all oral malignancies. Such metastases can occur to the bone or to the oral soft tissues [1-4]. The mandible is affected more frequently than the maxilla, with a predilection for the areas distal to the canines, including the body and ramus [5] . However, primary metastases to the soft tissues are extraordinarily rare, about $0.1 \%$ of oral malignancies $[6,7]$. The most common site for oral soft tissue metastases is the gingiva, which accounts for slightly more than $50 \%$ of all cases. This is followed by the tongue, which is the site for $25 \%$ of cases, lips, and the buccal and palatal mucosa $[\underline{2}, \underline{8}]$.

Almost any malignancy from any site is capable of metastasizing to the oral cavity, and a wide variety of tumours has been reported to spread to the mouth. The primary tumours are mainly located in lung, breast, and kidney. Other sites, in term of popularity, are the thyroid and prostate. Furthermore, organs of the gastrointestinal tract, particularly the stomach, have been described in few instances [7,9].

\section{CASE DESCRIPTIONS AND RESULTS}

In this article, we present three clinical cases, a female with invasive lobular breast carcinoma and two males with gastric adenocarcinoma and small cell lung carcinoma respectively, which metastasized to the oral cavity.

\section{Case presentation 1}

A 68-year-old female was referred to the Department of Oral and Maxillofacial Surgery of "Theageneio" Cancer Hospital of Thessaloniki, complaining of pain over the right half of the mandible.

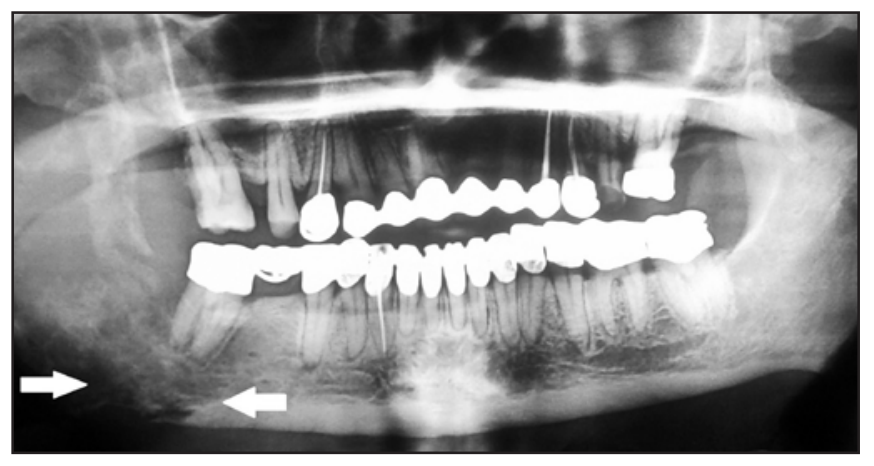

Figure 1. Orthopantomographic radiograph, showing the radiolucent lesion at the right mandibular body and ramus (arrows).
Intraoral examination showed a hard swelling over the posterior corpus and the ramus of the mandible. In the radiological examination with orthopantomographic radiograph (Figure 1), the trabecular pattern and bone density of the right mandibular body and ramus were distinctly altered. Diffuse osteolytic defect sites in the right half of the mandible were observed on the computed tomography (CT) of the head and face (Figure 2). No significant cervical lymphadenopathy was found.

Patient's medical history revealed that a partial mastectomy with axillary node dissection of levels I and II for the treatment of invasive lobular carcinoma was performed about 9 years before. The postoperative histology report showed an invasive lobular carcinoma with metastatic infiltration in 15 of 22 lymph nodes. Both estrogen (ER) and progesterone (PR) receptors were positive and c-erbB-2 negative. Overall, the carcinoma was staged as T2N3M0 and was treated with postoperatively chemotherapy and radiotherapy.

Under local anaesthesia, incisional biopsies of oral lesion were performed. The histological results supported evidence of metastatic invasive lobular carcinoma (Figure 3). Subsequently, a static scintigraphic image of the whole body was obtained. Bone scintigraphy showed isotope (technetium TC $99 \mathrm{~m}$ ) accumulation in the right half of the mandibular body, and occipital bone. After consultation with the Department of Medical Oncology further chemotherapy was decided. Zoledronic acid was administered.

Follow-up radiological examination by means of orthopantomography, almost 2 years after the mandibular metastases showed a pathologic fracture near the angle of the mandible without any other clinical findings, pain or movement (Figure 4). The patient died 6 months later.

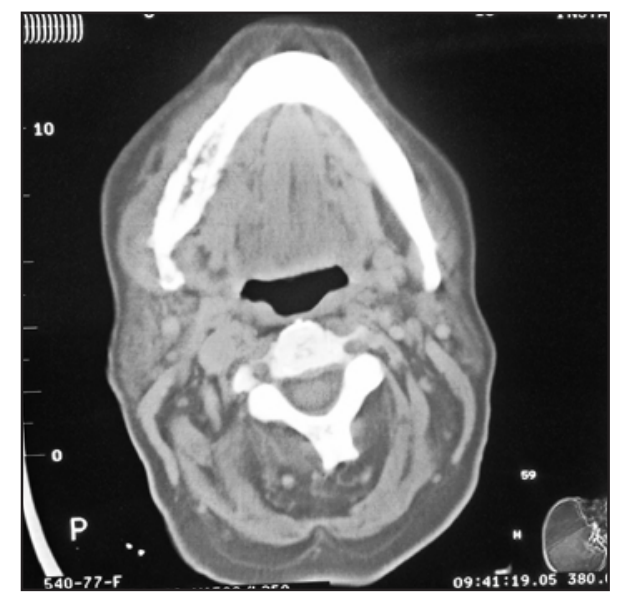

Figure 2. A computed tomography cross section of skull showing the diffuse osteolytic defect sites in the right half of mandible. 


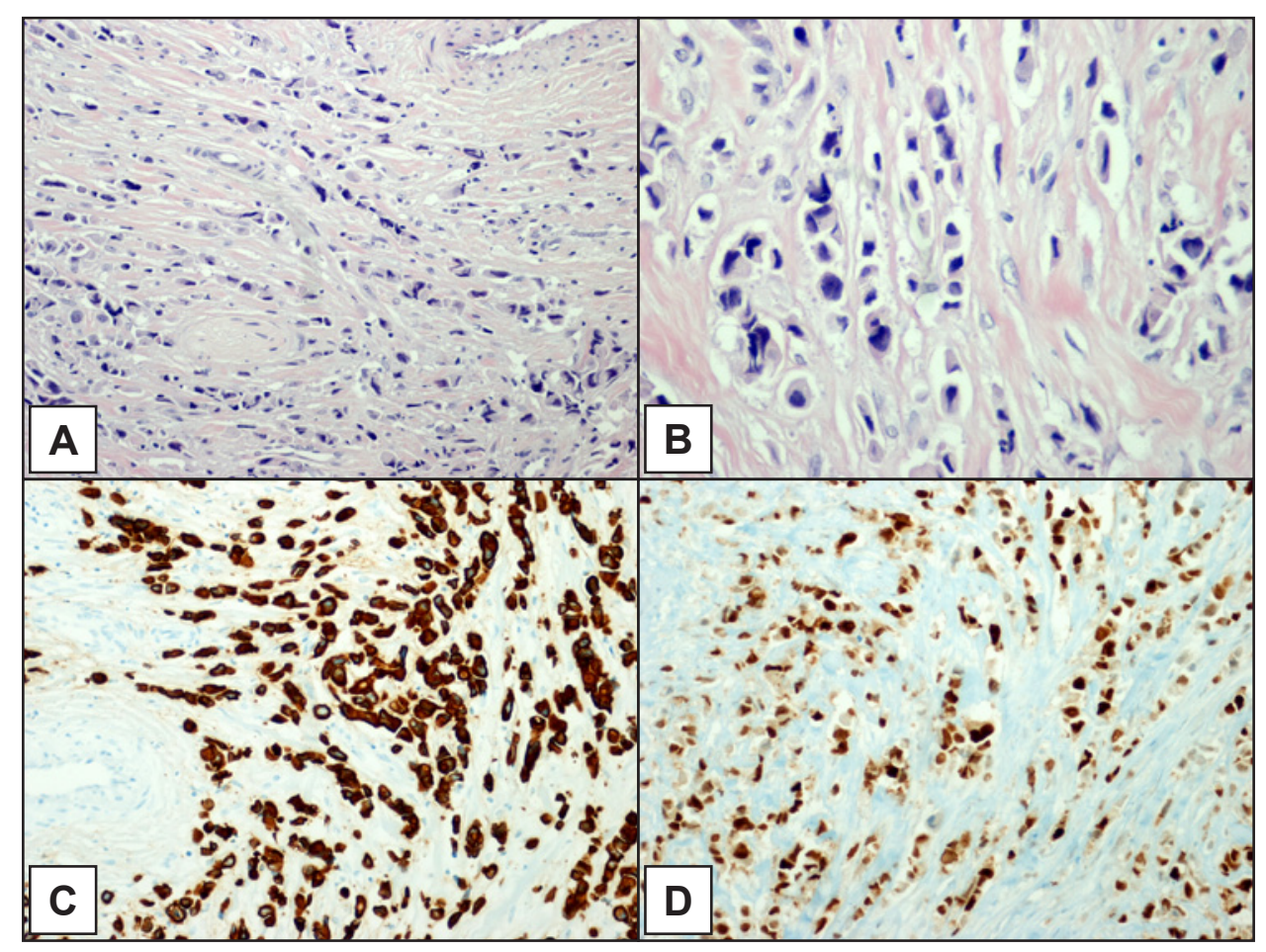

Figure 3. $\mathrm{A}=$ the neoplasm was composed of atypical non-cohesive cells individually arranged in a single-file linear pattern immersed in a fibrous stroma (hematoxylin and eosin stain, original magnification x200). B = single-file linear cords of atypical cells with plenty of pale cytoplasm and typical lack of cohesion were observed throughout the lesion (hematoxylin and eosin stain, original magnification $\mathrm{x} 400$ ). $\mathrm{C}=$ immunohistochemical staining for low-molecular-weight keratin confirmed the nature of the neoplastic cells (original magnification $\mathrm{x} 200$ ). $\mathrm{D}$ = strong estrogen receptor, immunohistochemical expression in many neoplastic cells (original magnification x200).

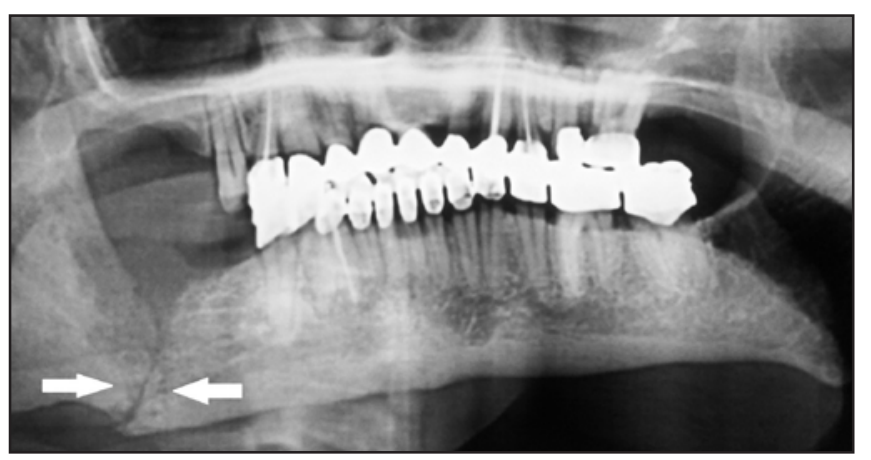

Figure 4. Orthopantomographic radiograph, showing the pathologic fracture near to the angle of the mandible (arrows).

\section{Case presentation 2}

A 71-year-old male patient was referred to our Department for consultation presenting with a main complaint of swelling in the anterior teeth space in the mandible. About 1 month earlier the patient visited his dentist because of a small swelling at the same region and mobility of the left mandibular central incisor. This was treated as a periodontal lesion by his dentist and the tooth was extracted.

The patient's previous medical history included subtotal gastrectomy with Billroth II anastomosis about 2 years before due to gastric adenocarcinoma. The postoperative histology report revealed a gastric adenocarcinoma enteric-type, poorly differentiated.
The tumour was composed of signet ring cells. Of 52 dissected nodes of omentum (greater and lesser), 26 nodes were cancer positive. Vascular, lymphatic and perineural invasion of cancer cells was observed. The margins of resection were reported free. The findings resulted in stage $\mathrm{pT} 3 \mathrm{pN} 3$. The patient received continuous 5-Fluorouracil in combination with Cisplatin postoperatively.

Under oral examination the patient presented with poor oral hygiene and a soft exophytic swelling over gingival, measuring $2 \times 2 \mathrm{~cm}$ with pinkish white colour, presenting a necrotic area of the distal margin and irregular surface. It was attached to the alveolar mucosa by a wide base (Figure 5). There was no evidence of cervical lymphadenopathy. Simple radiological study by means of orthopantomography highlighted (Figure 6) a radiolucent lesion of the mandible in the left anterior teeth space.

The intraoral lesion was biopsied and the histology report revealed gastric adenocarcinoma metastasis.

After the biopsy, the lesion rapidly enlarged causing a marked inability to masticate. The patient was admitted to the hospital and a marginal mandibulectomy in the anterior aspect of the oral cavity was performed (Figure 7, Figure 8). The surgical defect was repaired by primary closure of the mucosa of the floor of the mouth to the mucosa of the lower lip. 


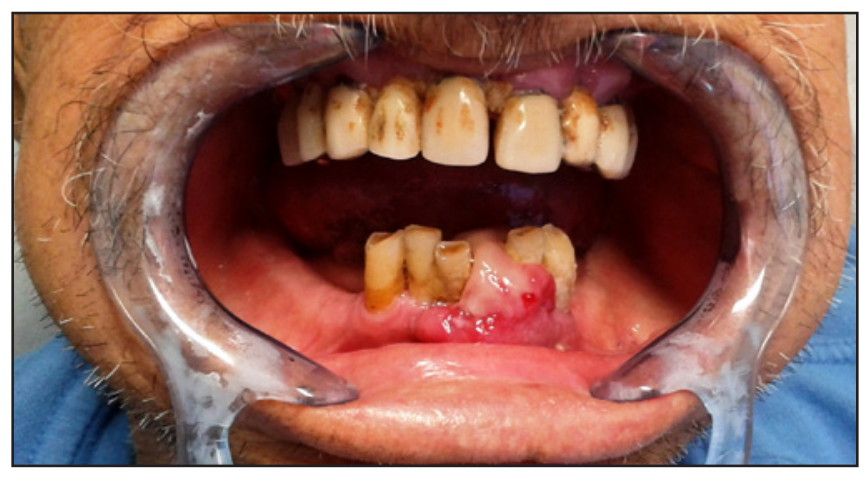

Figure 5. Intraoral photography showing the metastatic lesion in the anterior teeth space of the mandible.

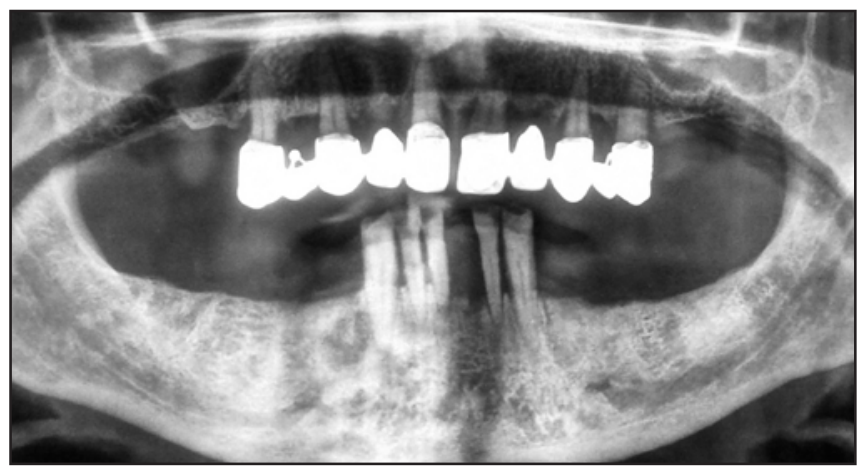

Figure 6. Orthopantomographic radiograph, showing the radiolucent lesion of the mandible in left anterior teeth space.

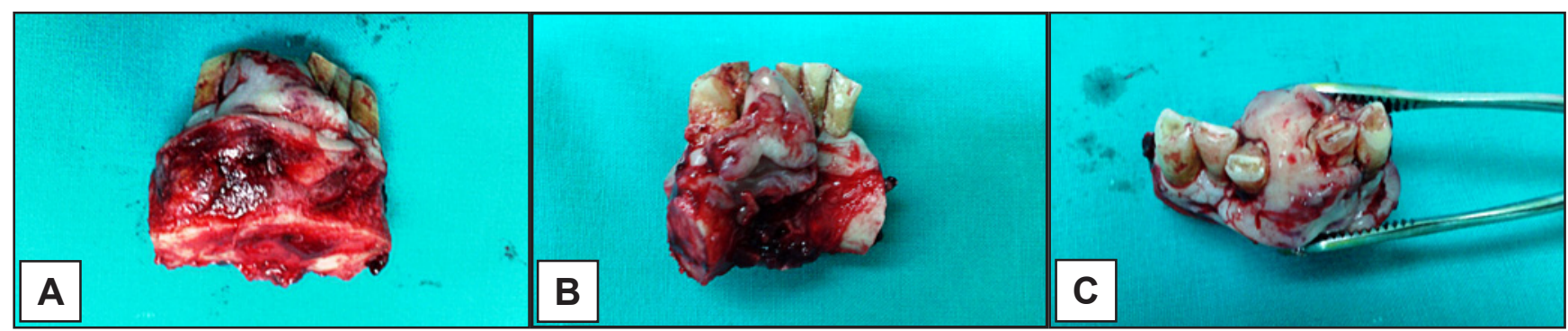

Figure 7. Marginal mandibulectomy specimens: $\mathrm{A}=$ anterior - inferior surface; $\mathrm{B}=$ posterior surface; $\mathrm{C}=$ superior surface.

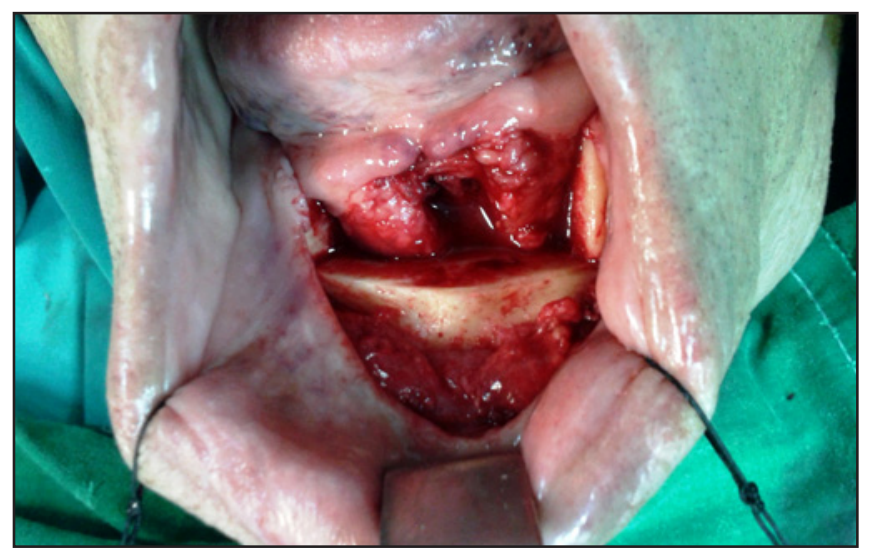

Figure 8. Intraoperative image after marginal mandibulectomy.

Histological examination showed a gastric adenocarcinoma moderately-poorly differentiated. The tumour cells infiltrated the dermis and focally the underlying bone. The margins of resection were free of tumour cells (Figure 9).

The patient made an uneventful postoperative recovery and was discharged 72 hours later. A clinical and radiological follow-up examination yielded no complication almost 2 months after the surgery (Figure 10 and 11).

\section{Case presentation 3}

A 69-year-old male patient was referred to the Theageneio Cancer Hospital of Thessaloniki with a complaint of increasing dyspnea and right-sited pleurodynia in August 2014. The CT scan of the chest revealed a right lung mass invading the mediastinum and the subcarinal bronchial obstruction. An abdominal CT scan showed multiple focal hypodense lesions of the liver and a solitary lesion of the spleen. Bone scintigraphy showed isotope (technetium TC $99 \mathrm{~m}$ ) accumulation in the 5th Lumbar (L5) vertebra. Fiberoptic bronchoscopy revealed an endobronchial mass in the bronchus of the right superior and middle lobes. Pathological examination of bronchial punch biopsies showed a small cell carcinoma. After confirmation of diagnosis, a chemotherapeutic regime of Carboplatin and Etoposide was selected.

During his hospitalization the patient presented continuous epigastric pain and a gastroscopy was performed which showed a gastric polypoid lesion. This lesion was histologically reported to be a metastasis from SCLC with identical morphological and immunohistochemistry pattern to the lung tumour (LMW-keratin,$+ \mathrm{CK} 7+$, TTF1+, focally positive for chromogranin and synaptophysin).

Unfortunately following the treatment, the patient presented to our Department for consultation showing a swelling of the anterior gingival of the mandible. This was a self-reported rapid growing lesion over two weeks' time enlarged to the point that interfered with his mastication, causing bleeding and pain. The patient had generalized lymphadenopathy.

Under oral examination, the patient presented with poor oral hygiene and a soft exophytic lesion over gingival, measuring $4 \times 5 \mathrm{~cm}$ with pinkish white colour and irregular surface. 


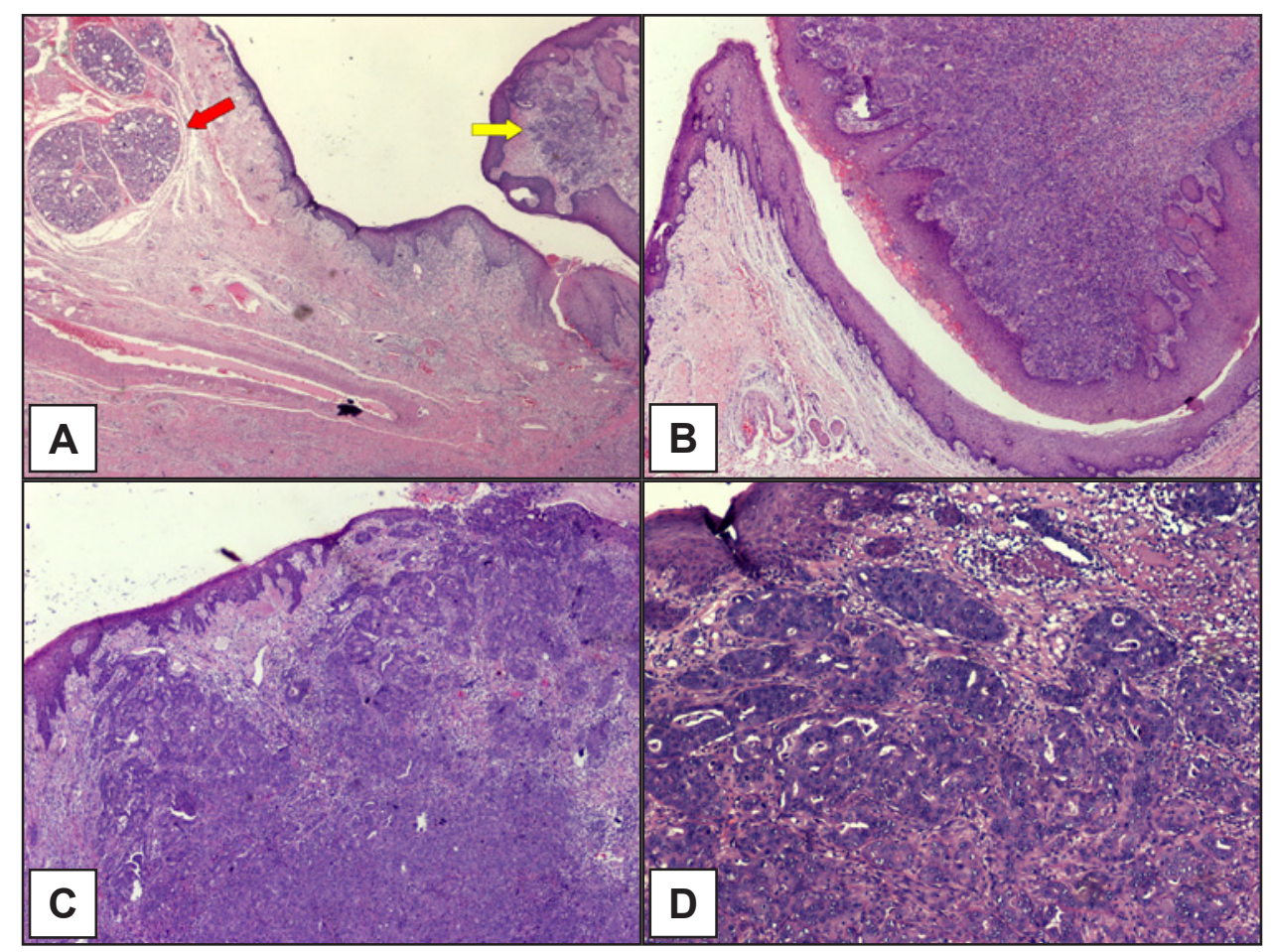

Figure 9. $\mathrm{A}$ = the tumour infiltrates the mucosa in the form of irregular islands and sheets (yellow arrow). Lobules of minor salivary glands (red arrow) (hematoxylin and eosin stain, original magnification $\mathrm{x} 40$ ). $\mathrm{B}=$ low magnification showing a poorly differentiated adenocarcinoma, characterized by solid and trabecular growth with isolated glandular structures (hematoxylin and eosin stain, original magnification $\mathrm{x} 100$ ). $\mathrm{C}=$ the tumour infiltrates beneath a surface squamous epithelium; the mucosa at the right is partly ulcerated (hematoxylin and eosin stain, original magnification $\mathrm{x} 100$ ). $\mathrm{D}=$ the tumour cells possess vesicular nuclei with prominent nucleoli. The mitotic rate is high (hematoxylin and eosin stain, original magnification $\mathrm{x} 200$ ).

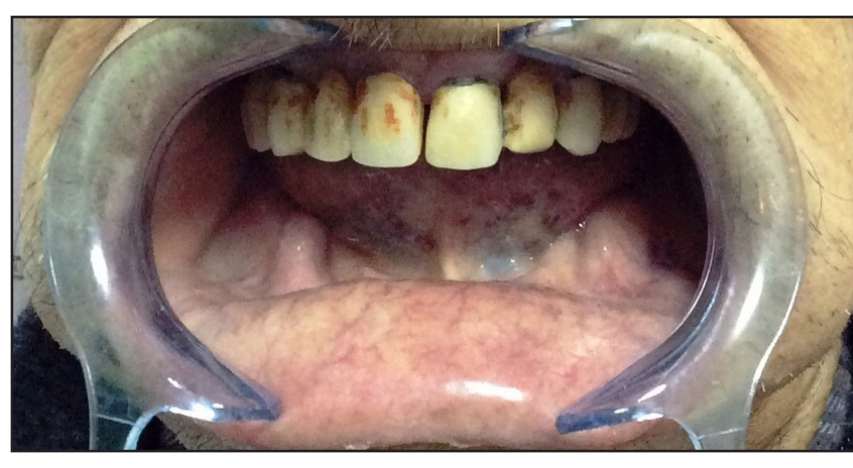

Figure 10. Intraoral photography 2 months after the surgery.

It was attached to the alveolar mucosa with a wide base (Figure 12). Simple radiological study by means of orthopantomography highlighted a radiolucent lesion in the right site of the mandible and anterior teeth dislocation (Figure 13).

The intraoral lesion was biopsied under local anaesthesia and the histopathology report revealed a high grade neuroendocrine carcinoma with elements of both small and large cell lung carcinoma (Figure 14). Due to the development of the oral metastasis, the patient exhibited a marked inability to masticate. He had been scheduled for surgical resection of the oral lesion. However, due to patient's deterioration of the general clinical condition the surgery was postponed. He suddenly died 2 weeks later.

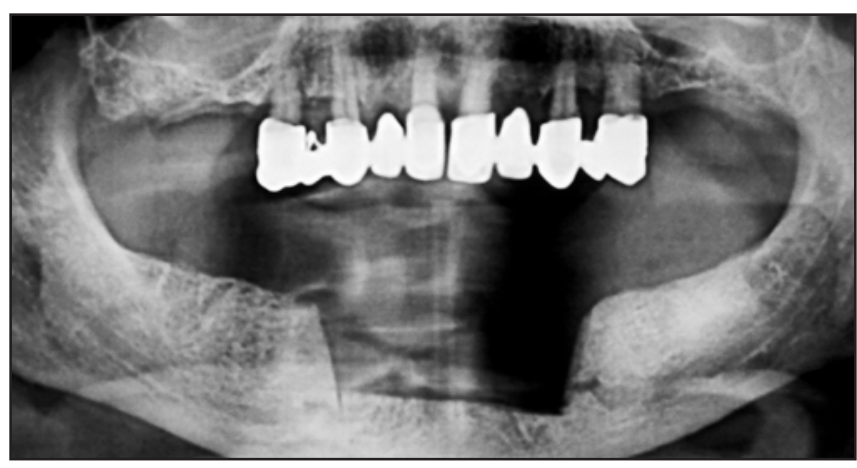

Figure 11. Orthopantomographic radiograph 2 months after the surgery.

\section{DISCUSSION}

The oral cavity is an uncommon site for metastatic tumours and it may occur both in the oral soft tissues or the jawbones. Because of their rarity, metastatic tumours to the oral region, pose a challenge for accurate diagnosis $[\underline{4}, \underline{8-12}]$.

Not infrequently, metastatic lesions are the first indication of an undiscovered primary malignancy. Hirshberg et al. [] showed in a review of 673 cases with metastatic oral lesions that these were the first indication of an undiscovered primary malignancy in $23 \%$ of cases. 


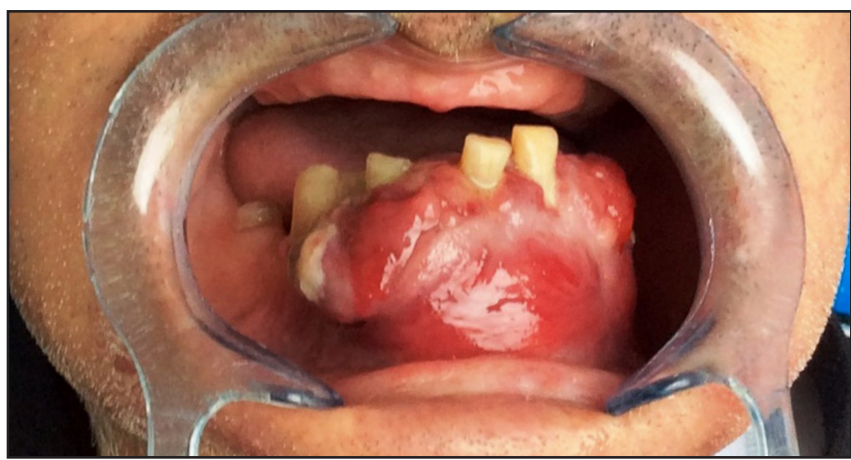

Figure 12. Intraoral photography showing the metastatic lesion.

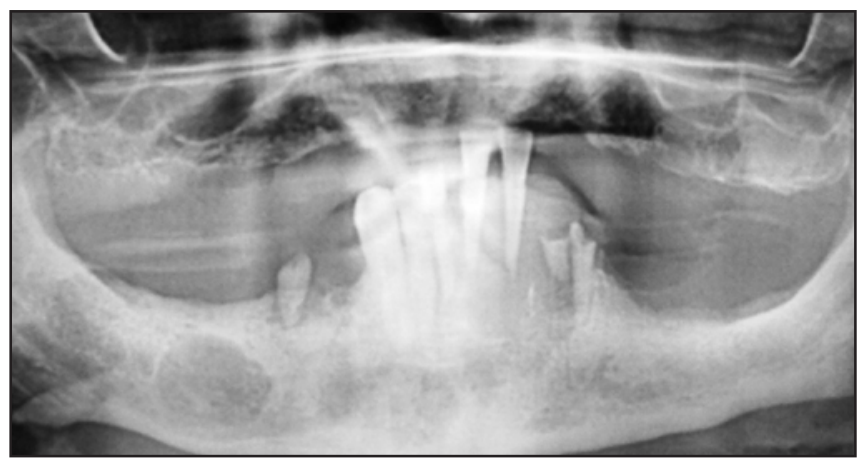

Figure 13. Orthopantomographic radiograph, showing the radiolucent lesion of the mandible and anterior teeth dislocation.

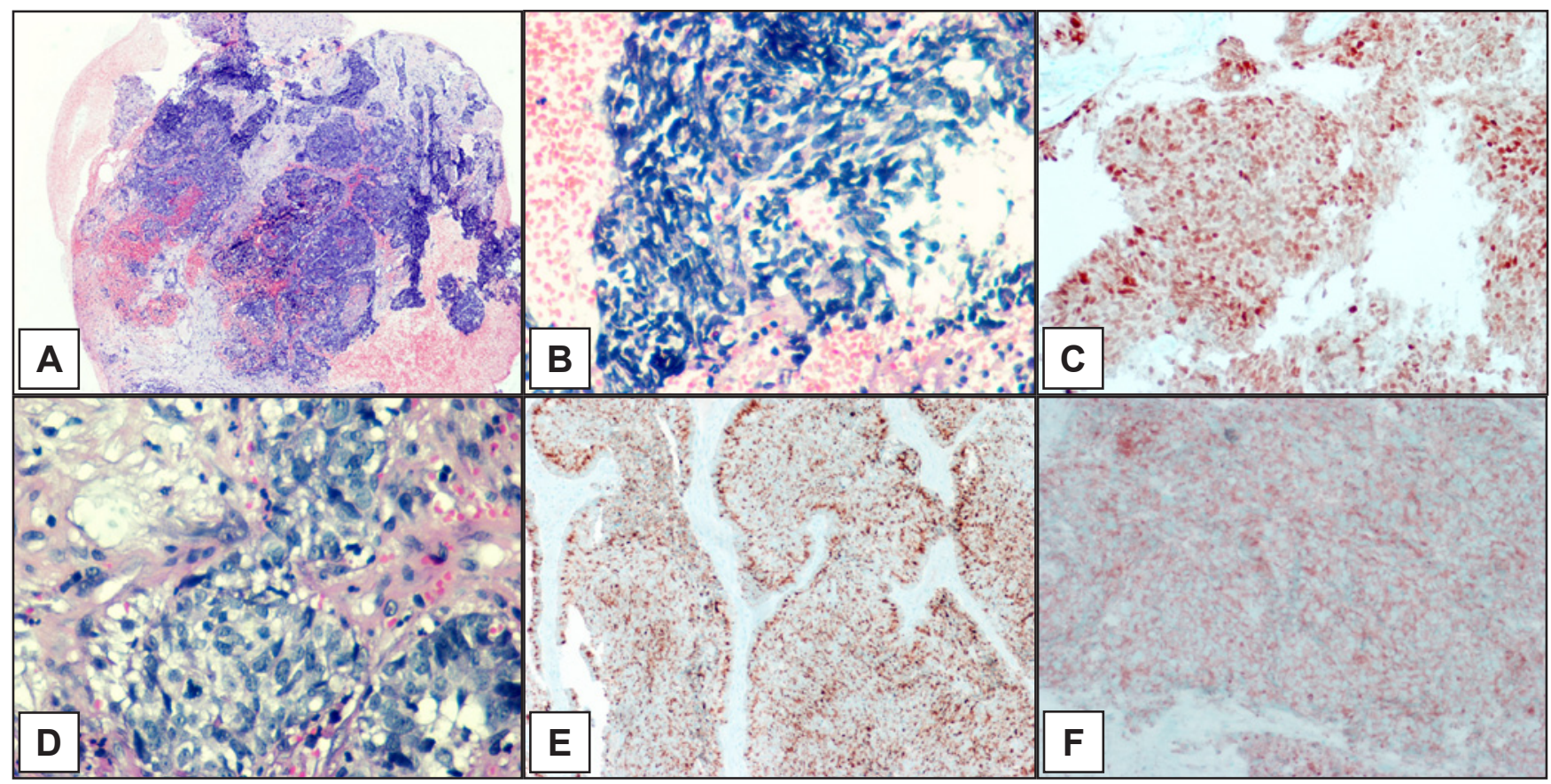

Figure 14. $\mathrm{A}$ = section of mucosa shows tumour infiltration of the underlying stroma. Surface is ulcerated (hematoxylin and eosin stain, original magnification $\mathrm{x} 40$ ). $\mathrm{B}=$ small cell carcinoma. Tumour cells are densely packed, with scant cytoplasm, finely granular nuclear and absence of nucleoli (hematoxylin and eosin stain, original magnification $\mathrm{x} 400$ ).

$\mathrm{C}=$ large cell component of the neoplasm has more cytoplasm and prominent nucleoli (hematoxylin and eosin stain, original magnification $\mathrm{x} 400$ ). $\mathrm{D}=\mathrm{TTF} 1$ immunoreactivity with a typical nuclear pattern (original magnification $\mathrm{x} 100$ ). $\mathrm{E}=$ chromogranin immunostaining shows a granular cytoplasmic pattern (original magnification $\mathrm{x} 100$ ). $\mathrm{F}=$ synaptophysin immunoreactivity with membranous staining pattern (original magnification x100).

In our cases the primary tumour was already diagnosed before the oral metastatic lesion appeared. Metastatic tumours to the jawbones are more frequently reported than those in the oral mucosa $[\underline{3}, \underline{8}, 12-15]$ and the ratio is approximately $2.5: 1[\underline{1}, \underline{8}]$. In Zachariades' review [9] of 422 metastatic oral cavity lesions, only $12(2.8 \%)$ involved soft tissues of the oral cavity. They are seen most frequently in middle-aged and older adults $[\underline{2}, \underline{13}, \underline{16}]$. However, patients with metastases to the jawbones are younger than those with metastases to the oral soft tissues $[12,17]$. According to some metaanalyses, the gender distribution of oral metastases is either predominantly male, approximately $2: 1$, respectively or almost equal, approximately $1.1: 1 \quad[\underline{3}, \underline{8}, \underline{13}, \underline{15}, \underline{18}]$. The range of time between diagnosis of the primary tumour and detection of oral metastatic disease is from 2 months to 3 years $[\underline{8}, \underline{17}]$.

The clinical presentations of the metastases include the pain, swelling, ulcer, trismus, paraesthesia, increasing tooth mobility, loose teeth, delayed healing of an extraction socket, masticatory difficulties, dysphagia, dyspnoea and pathological fracture. Paraesthesia in the mandibular metastasis is reported to be located in the area innervated by the mandibular alveolar dental nerve. A metastatic lesion in the oral soft tissue is more easily recognized. Gingival metastases usually appear as a polypoid or exophytic mass, highly vascularized and hemorrhagic $[\underline{4}, \underline{6}, \underline{7}, \underline{10}, \underline{17}, \underline{19-28}]$. 
Aforementioned signs and symptoms may lead to a misdiagnosis. The differential diagnosis includes hemangioma, pyogenic granuloma, giant-cell granuloma, peripheral fibroma, adenoid squamous cell carcinoma, polymorphous low-grade adenocarcinoma that affects the minor salivary glands of the mouth $[2,4,9,11,12,14,15,19,21,22,27,29-41]$. In our second case, the gingival lesion was first diagnosed as an inflammatory lesion and treated with tooth extraction and antibiotics, but the patient's symptoms deteriorated despite the treatment. Because such symptoms can mimic both benign and malignant lesions, biopsy and radiographic examination are indicated.

Metastatic tumour cell colonization is usually the evidence of a wide spread disease. The mechanism by which tumours can spread to the oral cavity is poorly understood. Primary malignancies from immediately adjacent tissues might be able to spread by a lymphatic route as well. However, such a mechanism cannot explain metastases of tumours from lower parts of the body, which are almost certainly blood borne and should be filtered out by the lungs. Batson proposed the valveless vertebral venous plexus as a mechanism for bypassing filtration through the lungs. Namely an increase in the intrathoracic pressure directs the blood flow into this system from the caval and azygous venous system and accounts for the increased distribution of axial skeleton and head and neck metastasis $[\underline{2}, \underline{31}]$.

The pathogenesis of the metastatic process in the jawbones is not clear, since they do not have much of active bone marrow, especially in elderly persons. The active marrow is a preferred site for metastatic deposits in the skeleton. Additionally, remnants of hematopoietic marrow can be found in an edentulous jaw in cases of focal osteoporotic bone marrow defects. These hematopoietically active sites may attract metastatic tumour cells [42].

In the oral soft tissues the metastatic tumours to the oral soft mucosa are found in the attached gingiva, whereas in edentulous patients, metastatic lesions are equally distributed between the tongue and the alveolar mucosa. The rich capillary network of chronically inflamed gingiva has been suggested as a mechanism that entraps malignant cells [31].

The most common histological type of metastatic tumours to the oral and maxillofacial region is adenocarcinomas [25], particularly breast adenocarcinoma which often metastasizes to the mandible or maxilla $[11,28,40,43]$. On the other hand, gastric adenocarcinoma infrequently metastasizes to the oral cavity with an extremely rare incidence. In the last 5 decades only 19 cases, have been reported in the literature [44].

The prognosis for metastatic neoplasms to the oral cavity is poor with an average survival period of about several months $[6-9,16,22,23,30,35,37-39,44-47]$. The treatment is directed towards palliation to improve the quality of life. A local excision may be performed to control pain, prevent bleeding and infection, and restore function. Radiotherapy can potentially aid in local symptoms control for a few months, while some cases may benefit from chemotherapy, even in disseminated disease. A complete evaluation of other organs is also important to formulate a treatment plan, as oral lesions may represent part of multiple metastases $[\underline{12}, \underline{31}, \underline{36}, \underline{39}, \underline{44}, \underline{46}]$.

\section{CONCLUSIONS}

In conclusion, metastases to the oral cavity are quite uncommon among general population. They usually present with symptoms similar to odontogenic infections and benign tumours, causing a delayed diagnosis and treatment. Consequently, careful examination and a high degree of clinical suspicion as well as a multidisciplinary approach are suggested, when examining patient with a personal history of malignancy.

\section{ACKNOWLEDGMENTS AND DISCLOSURE STATEMENTS}

The authors report no conflicts of interest related to this study.

\section{REFERENCES}

1. Hirshberg A, Buchner A. Metastatic tumours to the oral region. An overview. Oral Oncol, Eur J Cancer. 1995 Nov;31B(6):355-360. [Medline: $\underline{\text { 8746264] [doi: 10.1016/0964-1955(95)00031-3] }}$

2. Neville B, Damm D, Allen C, Bouquot J. Oral \& Maxillofacial Pathology. Philadelphia- Pennsylvania: W.B. Saunders Company; 2002 pp. 489-90.

3. van der Waal RIF, Buter J, van der Waal I. Oral metastases: report of 24 cases. British Journal of Oral and Maxillofacial Surgery. 2003 Feb;41(1):3-6. [Medline: 12576032] [doi: 10.1016/S0266-4356(02)00301-7] 
4. Raja Lakshmi C, Sudhakara Rao M, Bhavana SM, Sathish S. Primary squamous cell carcinoma of lung leading to metastatic jaw tumour. Case reports in pulmonology. Case Rep Pulmonol. 2014 Nov;2014:392616. [Medline: 25436166] [PMC free article: $\underline{4243604]}$ [doi: 10.1155/2014/392616]

5. Poulias E, Melakopoulos I, Tosios K. Metastatic breast carcinoma in the mandible presenting as a periodontal abscess: a case report. J Med Case Rep. 2011 Jul 1;5:265. [Medline: 21722359] [PMC free article: 3151228] [doi: $10.1186 / 1752-1947-5-265$ ]

6. Jain S, Kadian M, Khandelwal R, Agarwal U, Bhowmik KT. Buccal metastasis in a case of carcinoma breast: A rare case report with review of literature. Int J Surg Case Rep. 2013 Feb;4(4):406-8. [Medline: 23500744] [PMC free article: 3605473] [doi: 10.1016/j.ijscr.2013.02.001]

7. Colombo P, Tondulli L, Masci G, Muzza A, Rimassa L, Petrella D, Santoro A. Oral ulcer as an exclusive sign of gastric cancer: report of a rare case. BMC cancer. 2005 Sep;5:117. [Medline: 16171522] [PMC free article: 1242220] [doi: 10.1186/1471-2407-5-117]

8. Hirshberg A, Shnaiderman-Shapiro A, Kaplan I, Berger R. Metastatic tumours to the oral cavity - pathogenesis and analysis of 673 cases. Oral oncology. 2008 Aug;44(8):743-52. [Medline: 18061527] [doi: 10.1016/j.oraloncology.2007.09.012]

9. Zachariades N. Neoplasms metastatic to the mouth, jaws and surrounding tissues. J. CranioMaxillofac. Surg. 1989 Aug; 17 (6):283-90. [Medline: 2671045] [doi: 10.1016/S1010-5182(89)80098-8]

10. Kechagias N, Ntomouchtsis A, Patrikidou A, Christoforidou B, Andreadis C, Vahtsevanos K. Metastasis of a ductal breast carcinoma to the buccal mucosa of the mandible with tooth involvement. Oral Maxillofac Surg. 2012 Dec;16(4):377-81. [Medline: 22083239] [doi: 10.1007/s10006-011-0300-y]

11. Kumar G, Manjunatha B. Metastatic tumours to the jaws and oral cavity. Journal of oral and maxillofacial pathology. J Oral Maxillofac Pathol. 2013 Jan;17(1):71-5. [Medline: 23798834] [PMC free article: 3687193] [doi: 10.4103/0973-029X.110737]

12. Bodner L, Sion-Vardy N, Geffen D, Nash M. Metastatic tumours to the jaws: a report of eight new cases. Med Oral Patol Oral Cir Bucal. 2006 Mar 1;11(2):E132-5. [Medline: 16505790]

13. Daley T, Darling M. Metastases to the Mouth and Jaws: A Contemporary Canadian Experience. J Can Dent Assoc. 2011;77:b67. [Medline: 21683026]

14. Sánchez-Jiménez J, Acebal-Blanco F, Arévalo-Arévalo RE, Molina-Martínez M. Metastatic tumours in upper maxillary bone of esophageal adenocarcinoma. Med Oral Patol Oral Cir Bucal. 2005 May-Jul;10(3):252-7. [Medline: 15876970$]$

15. Lim SY, Kim SA, Ahn SG, Kim HK, Kim SG, Hwang HK, Kim BO, Lee SH, Kim JD, Yoon JH. Metastatic tumours to the jaws and oral soft tissues: a retrospective analysis of 41 Korean patients. Int J Oral Maxillofac Surg. 2006 May;35(5): 412-5. [Medline: 16473498] [doi: 10.1016/j.ijom.2005.12.001]

16. Irani S, Moshref M, Lotfi A. Metastasis of a gastric adenocarcinoma to the mandible. Oral Oncology Extra. 2004 Sep-Oct;40(8-9):85-7. [doi: 10.1016/j.ooe.2004.05.002]

17. Muttagi SS, Chaturvedi P, D'Cruz A, Kane S, Chaukar D, Pai P, Singh B, Pawar P. Metastatic tumours to the jaw bones: retrospective analysis from an Indian tertiary referral center. Indian J Cancer. 2011 Apr-Jun;48(2):234-9. [Medline: 21768673] [doi: 10.4103/0019-509X.82894]

18. Roh JL, Choi SH, Nam SY, Kim SY, Kim SB, Lee SW, Cho KJ. Metastatic carcinomas to the oral cavity and oropharynx. Korean J Pathol. 2012 Jun;46(3):266-71. [Medline: 23110013] [PMC free article: 3479763] [doi: 10.4132/KoreanJPathol.2012.46.3.266]

19. Umashankar D, Srinath N, Bavle RM, Bhandari A. Anterior maxillary metastasis of gastric adenocarcinoma: A rare case. J Oral Maxillofac Pathol. 2013 Sep;17(3):467-70. [Medline: 24574676] [PMC free article: 3927359] [doi: 10.4103/0973-029X.125223]

20. Dib LL, Soares AL, Sandoval RL, Nannmark U. Breast metastasis around dental implants: a case report. Clin Implant Dent Relat Research. 2007 Jun; 9(2):112-115. [Medline: 17535335] [doi: 10.1111/j.1708-8208.2007.00033.x]

21. Hwang KG, Park CJ, Paik SS, Shim KS. Gingival metastasis from gastric adenocarcinoma. Otolaryngol Head Neck Surg. 2007 Jul;137(1):169-70. [Medline: 17599589] [doi: 10.1016/j.otohns.2007.01.014]

22. Sasaki H, Ohara N, Minamikawa T, Umeda M, Komori T, Kojima N, Takemura N, Morita H, Sugihara R, Enoki E, Itoh T. Gingival Metastasis from Ovarian Mucinous. Kobe J. Med. Sci. 2008 Aug;54(3):E174-82. [Medline: 19246966]

23. Antunes AA, Antunes AP. Gnathic bone metastasis: a retrospective study of 10 cases. Braz J Otorhinolaryngol 2008 JulAug;74(4):561-5. [Medline: 18852982] [doi: 10.1590/S0034-72992008000400012]

24. Tamiolakis D, Tsamis I, Thomaidis V, Lambropoulou M, Alexiadis G, Venizelos I, Jivanakis T, Papadopoulos N. Jaw bone metastases: four cases. Acta Dermatovenerol Alp Pannonica Adriat. 2007 Mar;16(1):21-5. [Medline: 17992450]

25. Jham BC, Salama AR, McClure SA, Ord RA. Metastatic tumours to the oral cavity: a clinical study of 18 cases. Head Neck Pathol. 2011 Dec;5(4):355-8. [Medline: 21805337] [PMC free article: 3210225] [doi: $10.1007 / \mathrm{s} 12105-011-0286-7$ ]

26. Villa A, Mariani U, Villa F. Oral metastasis of lung cancer. A challenge for the clinician. Maxillofac Surg. 2012 Mar;16(1):133-5. [Medline: 21523354] [doi: 10.1007/s10006-011-0273-x]

27. Murillo J, Bagan JV, Hens E, Diaz JM, Leopoldo M. Tumours metastasizing to the oral cavity: a study of 16 cases. Journal of Oral and Maxillofacial Surgery. 2013 Sept;71(9):1545-1551. [Medline: 23800673] [doi: 10.1016/j.joms.2013.03.017] 
28. Khalili M, Mahboobi N, Shams J. Metastatic breast carcinoma initially diagnosed as pulpal/periapical disease: a case report. J Endod. 2010 May;36(5):922-5. [Medline: 20416447] [doi: 10.1016/j.joen.2010.01.010]

29. Spinelli GP, Caprio G, Tomao F, Barberi S, Miele E, Boghi F, Costarelli L, Tomao S. Metastatic infiltration of adenocarcinoma of the rectum in hard palate: Report of a case and a review of the literature. Oral Oncology Extra. 2006 May;42(5):206-9. [doi: 10.1016/j.ooe.2005.12.002]

30. Munakata R, Sawair FA, Cheng J, Saku T. Gingival metastasis of ovarian carcinoma: report of a case and review of the literature. Int J Oral Maxillofac Surg. 2009 Oct;38(10):1123-6. [Medline: 19505797] [doi: 10.1016/j.ijom.2009.05.003]

31. Hirshberg A, Berger R, Allon I, Kaplan I. Metastatic tumours to the jaws and mouth. Head Neck Pathol. 2014 Dec;8(4):46374. [Medline: 25409855] [PMC free article: 4245411] [doi: 10.1007/s12105-014-0591-z]

32. Seoane J, Van der Waal, Van der Waal R, Cameselle-Teijeiro J, Antón I, Tardio A, Alcázar-Otero JJ, VarelaCentelles P, Diz P. Metastatic tumours to the oral cavity: a survival study with a special focus on gingival metastases. J Clin Periodontol. 2009 Jun;36(6):488-92. [Medline: 19508248] [doi: 10.1111/j.1600-051X.2009.01407.x]

33. Pektas ZO, Gunhan O. Cytologically diagnosed metastatic small cell lung carcinoma in the mandibular soft tissue. Saudi medical journal.2013 May;34(5):539-41. [Medline: 23677273]

34. Jaguar GC, Prado JD, Soares F, Alves FA, Toleda Osório CA. Gingival metastasis from non-small cell undifferentiated carcinoma of the lung mimicking a pyogenic granuloma. Oral Oncology Extra. 2006 Jan;42(1):36-9. [doi: 10.1016/j.ooe.2005.08.007]

35. Watanabe E, Touge H, Tokuyasu H, Kawasaki Y. Gingival metastasis of adenocarcinoma from the lung. Respiratory Medicine CME. 2008 Jan;1(2):103-6. [doi: 10.1016/j.rmedc.2007.12.006]

36. Huang CJ, Chang YL, Yang MC, Hsueh C, Yu CT. Lung cancer metastatic to the maxillary gingiva: A case report and literature review. Oral Oncol Extra. 2005 Jul;41:118-20. [doi: 10.1016/j.ooe.2005.02.007]

37. Beena V, Panda S, Heera R, Rajeev R. (2011) Multiple metastatic tumours in the oral cavity. J Oral Maxillofac Pathol. 2011 May;15(2):214-8. [Medline: 22529584] [PMC free article: 3329702] [doi: 10.4103/0973-029X.84508]

38. Abbaszadeh-Bidokhty H, Motallebnejad M, Rajabi-Moghaddam M. Metastatic Renal cell Carcinoma Presenting as a clear-cell Tumour in Tongue: A Case Report. Iranian journal of otorhinolaryngology. 2014 Jul;26(76):185-90. [Medline: 25009810] [PMC free article: 4087859]

39. Curien R, Moizan H, Gerard E. Gingival metastasis of a bronchogenic adenocarcinoma: report of a case. Oral Surgery, Oral Med, Oral Pathol, Oral Radiol Endod. 2007 Dec;104(6):e25-8. [Medline: 17942337] [doi: 10.1016/j.tripleo.2007.06.021]

40. Maschino F, Guillet J, Curien R, Dolivet G, Bravetti P. Oral metastasis: a report of 23 cases. Int J Oral Maxillofac Surg. 2013 Feb;42(2):164-8. [Medline: 23196066] [doi: 10.1016/j.ijom.2012.10.029]

41. Ravi Prakash SM, Verma S, Gill N, Malik V. Multiple gingival metastasis of adenocarcinoma of the lung. Indian J Dent Res. 2012 Jul-Aug;23(4):558-9. [Medline: 23257503] [doi: 10.4103/0970-9290.104978]

42. Valastyan S, Weinberg RA. Tumor metastasis: molecular insights and evolving paradigms. Cell. 2011 Oct 14;147(2):27592. [Medline: 22000009] [PMC free article: 3261217] [doi: 10.1016/j.cell.2011.09.024]

43. Adelson RT, DeFatta RJ, Miles BA, Hoblitt SL, Ducic Y. Metastatic breast cancer of the oral cavity. Am J of Otolaryngology. 2005 Jul-Aug;26(4):279-81. [Medline: 15991097] [doi: 10.1016/j.amjoto.2005.01.008]

44. Sauerborn D, Vidakovic B, Baranovic M, Mahovne I, Danic P, Danic D. Gastric adenocarcinoma metastases to the alveolar mucosa of the mandible: a case report and review of the literature. J Craniomaxillofacial Surg. 2011 Dec;39(8):645-8. [Medline: 21112790] [doi: 10.1016/j.jcms.2010.10.020]

45. Shimoyama S, Seto Y, Aoki F, Ogawa T, Toma T, Endo H, Itouji T, Kaminishi M. Gastric cancer with metastasis to the gingiva. J Gastroenterol Hepatol. 2004 Jul; 19(7):831-5. [Medline: 15209637] [doi: 10.1111/j.1440-1746.2002.03234.x]

46. Abiko Y, Ogawa I, Hattori Y, Kusano K, Nishimura M, Ohuchi T, Abe U, Shibata T, Matsuda S, Takata T, Kaku T. Atypical carcinoid (neuroendocrine carcinoma) of the gingiva: counterpart of a laryngeal tumour. Pathol Int. 2004 Feb;54(2):97100. [Medline: 14720139] [doi: 10.1111/j.1440-1827.2004.01598.x]

47. Alvarez-Alvarez C, Iglesias-Rodríguez B, Pazo-Irazu S, Delgado-Sánchez-Gracián C. Colonic adenocarcinoma with metastasis to the gingiva. Med Oral Patol Oral Cir Bucal. 2006 Jan 1;11(1):E85-7. [Medline: 16388302]

\section{To cite this article:}

Kalaitsidou IG, Astreidis IT, Kontos KI, Lazaridou MN, Bourlidou ET, Gerasimidou DK, Vladika NP, Mangoudi DL.

Metastatic Tumours to the Oral Cavity: Report of Three Cases

J Oral Maxillofac Res 2015;6(4):e5

URL: http://www.ejomr.org/JOMR/archives/2015/4/e5/v6n4e5.pdf

doi: $10.5037 /$ jomr.2015.6405 
Copyright (C) Kalaitsidou IG, Astreidis IT, Kontos KI, Lazaridou MN, Bourlidou ET, Gerasimidou DK, Vladika NP, Mangoudi DL. Published in the JOURNAL OF ORAL \& MAXILLOFACIAL RESEARCH (http://www.ejomr.org), 31 December 2015.

This is an open-access article, first published in the JOURNAL OF ORAL \& MAXILLOFACIAL RESEARCH, distributed under the terms of the Creative Commons Attribution-Noncommercial-No Derivative Works 3.0 Unported License, which permits unrestricted non-commercial use, distribution, and reproduction in any medium, provided the original work and is properly cited. The copyright, license information and link to the original publication on (http://www.ejomr.org) must be included. 